\title{
COUPLING OF DIHYDRORIBOFLAVIN OXIDATION TO THE FORMATION OF THE HIGHER VALENCE STATES OF HEMEPROTEINS
}

\author{
Feng Xu and Donald E. Hultquist* \\ Department of Biological Chemistry \\ Medical School \\ The University of Michigan \\ Ann Arbor, Michigan 48109-0606
}

Received October 7, 1991

SUMMARY: The reactions between hydrogen peroxide and hemeproteins have been coupled to the oxidation of dihydroriboflavin so as to provide a simple method for measuring the rate constant of hemeprotein peroxidation. Dihydroriboflavin rapidly reduces the higher oxidation states of iron and the hydroxy radicals which are the products of the hemeprotein / hydrogen peroxide reaction. The rapid reduction of these highly reactive compounds prevents the hemeproteins from undergoing irreversible chemical modifications and thus allows the kinetics of peroxidation to be studied. The rate constants at $\mathrm{pH} 7.2$ and $23^{\circ} \mathrm{C}$ for the peroxidation of horseradish peroxidase, myoglobin, and ferrocytochrome $c$ are found to be $6.2 \times 10^{6}, 7.5 \times 10^{4}$, and $8 \times 10^{3} \mathrm{M}^{-1} \mathrm{~s}^{-1}$, respectively. These studies suggest that reduced riboflavin might efficiently protect cells from oxidative damage such as that occurring in inflammation and reperfusion injury. 1991 Academ1c Press, Inc.

The higher oxidation states of peroxidases are participants in the catalytic mechanisms of these enzymes. In order to better understand the structure-activity relationships, the higher oxidation states generated by mixing peroxidases and peroxides have been detected, quantitated, and studied extensively by direct uv-visible spectroscopy (1-3).

Such experiments are difficult or impossible to conduct with many hemeproteins other than peroxidases because of the high reactivities of their higher oxidation states. With such hemeproteins, the higher oxidation state derivatives undergo reactions which lead to irreversible modification and inactivation of the proteins and degradation of cellular components (1-12). In the presence of peroxides, hemeproteins catalyze the peroxidation of cellular lipids $(5,6,13-17)$. The ferryl, $\mathrm{Fe}(\mathrm{IV}) \mathrm{O}$, form of myoglobin has been postulated to be critical in the damage associated with reperfusion injury of cardiac and other muscles $(18,19)$.

In this paper we report a simple method for measuring rates of hemeprotein peroxidation based on the rapid reduction of the higher oxidation states by dihydroriboflavin. The method is not limited to those hemeproteins with stable higher oxidation states and is thus a useful technique for studying the mechanism of peroxide-dependent, hemeprotein-catalyzed cellular damage. The results of these studies suggest that reduced flavins might play a role in protecting cells from oxidative damage induced by hemeproteins in the presence of peroxide.

* To whom correspondence should be addressed. 


\section{MATERIALS AND METHODS}

Materials. Horse heart metmyoglobin was obtained from ICN, horse heart ferricytochrome $c$ (type III) and horseradish peroxidase were from Sigma, and riboflavin from Eastman. Hydrogen peroxide (30\%) from EM Science was quantitated by photometry at $240 \mathrm{~nm}\left(\varepsilon=43.6 \mathrm{M}^{-1} \mathrm{~cm}^{-1}\right)$.

General methods. Buffers for kinetic studies were prepared with sodium acetate (pH 3-5), potassium phosphate ( $\mathrm{pH} \mathrm{6-8)}$ ), and sodium carbonate ( $\mathrm{pH}$ 9-11). Spectral studies were conducted with a Uvikon Kontron 810 spectrophotometer using 1-cm light-path quartz cuvettes.

Photochemical reductions were carried out using EDTA as the source of electrons (20-22). The sample containing riboflavin and hemeprotein was placed in a quartz cuvette immersed in a Pyrex ice-water bath and flushed with $\mathrm{N}_{2}$ in the dark for $20 \mathrm{~min}$. In the dark, no reduction occurred on the experimental time-scale. Irradiation was carried out with a 650 -watt tungsten-halogen lamp and the extent of reduction of riboflavin and ferric hemeprotein was spectrally monitored. During the irradiation, residual $\mathrm{O}_{2}$ was eliminated thereby avoiding complicating oxidation reactions. A 5-min exposure was more than sufficient to completely reduce flavin and the ferric forms of myoglobin and cytochrome $c$. The ferric form of horseradish peroxidase was not reduced under these conditions.

The rate of formation of ferryl myoglobin from myoglobin and $\mathrm{H}_{2} \mathrm{O}_{2}$ was measured directly by spectrophotometry $(10,18)$. Metmyoglobin $(0.2$ to $2 \mu \mathrm{M})$ was first subjected to photochemical reduction with $0.03 \mu \mathrm{M}$ riboflavin and $0.4 \mathrm{mM}$ EDTA in $17 \mathrm{mM}$ potassium phosphate, $\mathrm{pH} 7.2$, at $23^{\circ} \mathrm{C}$. The formation of the ferryl state of myoglobin was initiated by adding $\mathrm{H}_{2} \mathrm{O}_{2}$ in 1 to 10 -fold excess over myoglobin under anaerobic conditions. Absorbance in the Soret region was followed with time and the spectrum of the final product was recorded. The riboflavin concentration was sufficiently low to avoid reducing ferryl myoglobin with dihydroflavin to a significant extent, but high enough to accomplish the photochemical reduction of metmyoglobin.

$A$ method for measuring the rate of hemeprotein peroxidation by coupling to dihydroriboflavin oxidation. The reactions of myoglobin, ferrocytochrome $c$, and horseradish peroxidase with $\mathrm{H}_{2} \mathrm{O}_{2}$ were studied at $23^{\circ} \mathrm{C}$ by coupling to the oxidation of dihydroriboflavin. Rates were determined using 0.003 to $5 \mu \mathrm{M}$ hemeprotein, 10 to $100 \mu \mathrm{M}$ riboflavin, 0.5 to $10 \mu \mathrm{M} \mathrm{H}_{2} \mathrm{O}_{2}, \sim 1 \mathrm{mM}$ EDTA, and 10 to $35 \mathrm{mM}$ buffer. The sample containing riboflavin, hemeprotein, EDTA, and buffer was made anaerobic, and a few $\mu \mathrm{l}$ of an anaerobic solution of $\mathrm{H}_{2} \mathrm{O}_{2}$ were then placed on the wall of the cuvette such that there was no mixing with the sample. After five min of flushing with $\mathrm{N}_{2}$, the sample was subjected to photoreduction as described above. The peroxidation was then initiated by mixing the $\mathrm{H}_{2} \mathrm{O}_{2}$ and sample. The final concentration of dihydroriboflavin was greater than the final concentration of $\mathrm{H}_{2} \mathrm{O}_{2}$, so that the hemeprotein was protected during the reaction cycles. The oxidation of dihydroriboflavin was monitored by absorbance at $445 \mathrm{~nm}\left(\varepsilon=12.2 \mathrm{mM}^{-1} \mathrm{~cm}^{-1}\right)$. Second-order rate constants were derived from either the dependence of the observed pseudo-first order rates on hemeprotein concentration or the dependence of the initial rates on $\mathrm{H}_{2} \mathrm{O}_{2}$ and hemeprotein concentrations. Corrections were made for the direct reaction of dihydroriboflavin with $\mathrm{H}_{2} \mathrm{O}_{2}$.

\section{RESULTS}

Addition of $\mathrm{H}_{2} \mathrm{O}_{2}$ to a photochemically-reduced mixture of riboflavin and hemeprotein initiated coupled oxidation of dihydroriboflavin to riboflavin, as exemplified in Fig. 1. In the $\mathrm{pH}$ range 3 to 8 , the oxidation in the absence of hemeprotein was negligible in comparison with the hemeproteinstimulated reaction. The observed initial reaction rates with horseradish peroxidase, myoglobin, and ferrocytochrome $c$ increase linearly with hemeprotein concentration and $\mathrm{H}_{2} \mathrm{O}_{2}$ concentration, but are independent of dihydroriboflavin concentration. The observed half-life times of reaction show linear dependence on hemeprotein concentration. Thus the reactions are first-order with respect to hemeprotein and $\mathrm{H}_{2} \mathrm{O}_{2}$ and zero-order with respect to dihydroriboflavin. In each of the 

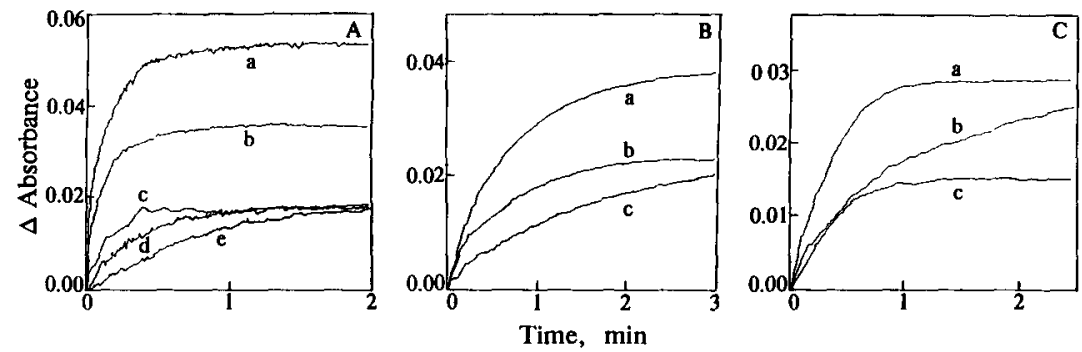

FIG. 1. Hemeprotein peroxidations as followed by coupling the reaction to dihydroriboflavin oxidation. Change of absorbance at $445 \mathrm{~nm}$ was monitored with time. All solutions contained $0.93 \mathrm{mM}$ EDTA and $33 \mathrm{mM}$ potassium phosphate buffer, $\mathrm{pH}$ 7.2. (A) Horseradish peroxidase in the presence of $42 \mu \mathrm{M}$ dihydroriboflavin. a, $13 \mathrm{nM}$ peroxidase and $5.2 \mu \mathrm{M} \mathrm{H}_{2} \mathrm{O}_{2} ; \mathrm{b}, 13 \mathrm{nM}$ peroxidase and $3.7 \mu \mathrm{M} \mathrm{H}_{2} \mathrm{O}_{2} ; \mathrm{c}, 13 \mathrm{nM}$ peroxidase and $1.4 \mu \mathrm{M} \mathrm{H}_{2} \mathrm{O}_{2} ; \mathrm{d}, 6.6 \mathrm{nM}$ peroxidase and $1.4 \mu \mathrm{M} \mathrm{H}_{2} \mathrm{O}_{2}$; e, $3 \mathrm{nM}$ peroxidase and $1.4 \mu \mathrm{M} \mathrm{H}_{2} \mathrm{O}_{2}$. (B) Myoglobin in the presence of $22 \mu \mathrm{M}$ dihydroriboflavin. a, $0.43 \mu \mathrm{M}$ myoglobin and $3.7 \mu \mathrm{M} \mathrm{H}_{2} \mathrm{O}_{2} ; \mathrm{b}, 0.43 \mu \mathrm{M}$ myoglobin and $2.2 \mu \mathrm{M}$ $\mathrm{H}_{2} \mathrm{O}_{2} ; \mathrm{c}, 0.22 \mu \mathrm{M}$ myoglobin and $2.2 \mu \mathrm{M} \mathrm{H}_{2} \mathrm{O}_{2}$. (C) Ferrocytochrome $c$ in the presence of 21 $\mu \mathrm{M}$ dihydroriboflavin. a, $4.5 \mu \mathrm{M}$ cytochrome $c$ and $2.4 \mu \mathrm{M} \mathrm{H}_{2} \mathrm{O}_{2} ; \mathrm{b}, 2.3 \mu \mathrm{M}$ cytochrome $c$ and $2.4 \mu \mathrm{M} \mathrm{H}_{2} \mathrm{O}_{2} ;$ c, $4.5 \mu \mathrm{M}$ cytochrome $c$ and $1.2 \mu \mathrm{M} \mathrm{H}_{2} \mathrm{O}_{2}$.

reactions, the stoichiometry is $1.0 \pm 0.2$ mole of dihydroriboflavin oxidized per mole of $\mathrm{H}_{2} \mathrm{O}_{2}$ consumed and the final spectrum of the oxidized dihydroriboflavin is identical to that of riboflavin.

As measured with this coupling system, the second-order rate constants, $k$, of hemeprotein peroxidations at neutral $\mathrm{pH}$ and $23^{\circ} \mathrm{C}$ are $6.2 \times 10^{6}, 7.5 \times 10^{4}$, and $8 \times 10^{3} \mathrm{M}^{-1} \mathrm{~s}^{-1}$ for horseradish peroxidase, myoglobin, and ferrocytochrome $c$, respectively. The rate constants are unchanged over the $\mathrm{pH}$ range from 3 to 8 (Fig. 2). In alkaline solution ( $\mathrm{pH} 8-10$ ) the plots of $\log k v s \mathrm{pH}$ show a slope of -1 , indicating the involvement of a single proton-dissociating group. $p K_{\mathrm{a}}$ values of 9.2, 8.2, and 7.8 were obtained for horseradish peroxidase, myoglobin, and ferrocytochrome $c$, respectively. Spectral analysis shows that during the course of the reaction, both myoglobin and cytochrome $c$ remain in the ferrous state generated by the photochemical reduction procedure, but horseradish peroxidase remains in the ferric state both after the photochemical reduction procedure and during the peroxidation reaction (Fig. 3).

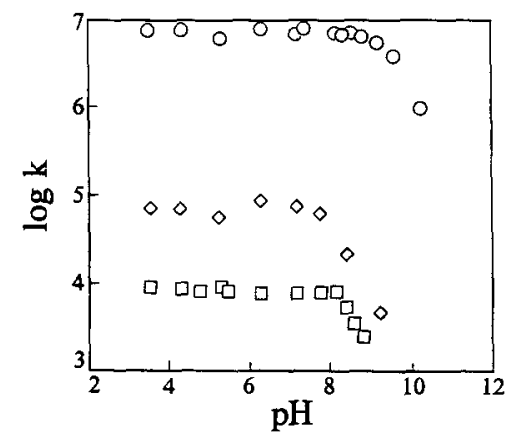

FIG. 2. pH profiles of the secondary rate constants for peroxidation of hemeproteins. See text for details. 

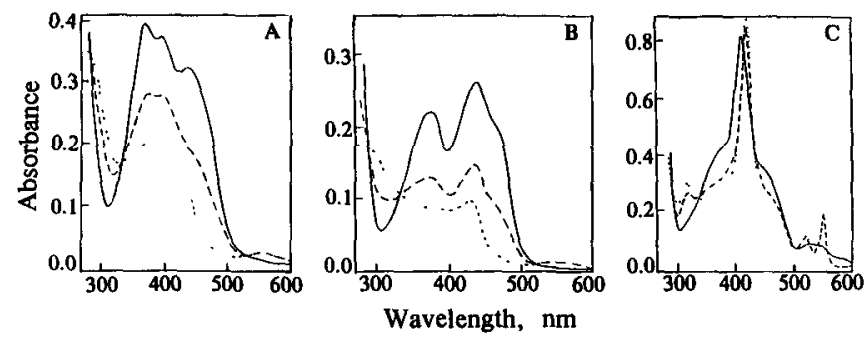

FIG. 3. Spectral changes occurring upon hemeprotein peroxidations. (A)Horseradish peroxidase. The solution contained $1.9 \mu \mathrm{M}$ horseradish peroxidase, $14 \mu \mathrm{M}$ riboflavin, $0.9 \mathrm{mM}$ EDTA, and 16 $\mathrm{mM}$ potassium phosphate buffer, $\mathrm{pH}$ 7.2. (-), before irradiation; $(\cdots)$, after irradiation; $(--), 5$ min after the solution was made $8 \mu \mathrm{M}$ in $\mathrm{H}_{2} \mathrm{O}_{2}$. (B) Myoglobin. The solution contained $0.5 \mu \mathrm{M}$ metmyoglobin, $20 \mu \mathrm{M}$ riboflavin, $1 \mathrm{mM}$ EDTA, and $35 \mathrm{mM}$ sodium acetate buffer, $\mathrm{pH}$ 5.3. (-), before irradiation; ( . .), after irradiation; (-- ), 10 min after the solution was made $7 \mu \mathrm{M}_{\text {in }} \mathrm{H}_{2} \mathrm{O}_{2}$. (C) Cytochrome $c$. The solution contained $4.5 \mu \mathrm{M}$ cytochrome $c, 20 \mu \mathrm{M}$ riboflavin, $0.9 \mathrm{mM}$ EDTA, and $33 \mathrm{mM}$ potassium phosphate buffer, $\mathrm{pH}$ 7.2. (-), before irradiation; ( . . ) after irradiation; (-- ), 15 min after the solution was made $10 \mu \mathrm{M}$ in $\mathrm{H}_{2} \mathrm{O}_{2}$.

As measured by direct spectrophotometry (Fig. 4), the formation of ferryl myoglobin from myoglobin and $\mathrm{H}_{2} \mathrm{O}_{2}$ followed simple second-order kinetics. A rate constant of $8.0 \times 10^{4} \mathrm{M}^{-1} \mathrm{~s}^{-1}$ was calculated. During the peroxidation, the appearance of a spectrum with absorbance maxima at 424,550 , and $584 \mathrm{~nm}$ confirmed that ferryl myoglobin is the primary product of this reaction (10). After a few minutes of reaction, the ferryl myoglobin began to gradually revert to the ferric form. Under the same conditions, it was not possible to directly measure the formation of peroxidation products of cytochrome $c$ because a rapid bleaching reaction occurred immediately after mixing ferrocytochrome $c$ with $\mathrm{H}_{2} \mathrm{O}_{2}$.

\section{DISCUSSION}

The coupling of dihydroriboflavin oxidation to the reactions between hemeproteins and $\mathrm{H}_{2} \mathrm{O}_{2}$ provides the basis for a convenient and rapid method for measuring the rates of peroxidation of
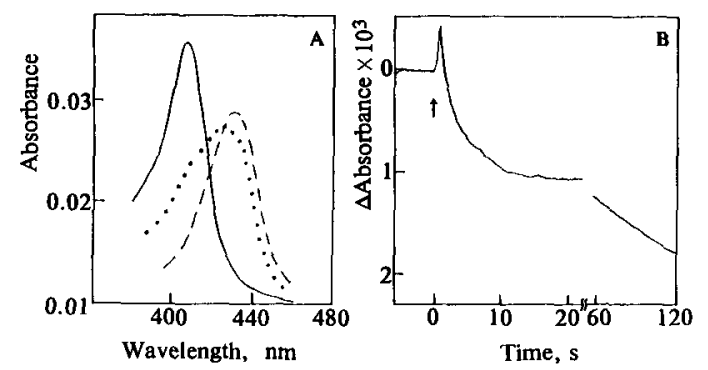

FIG. 4. Reaction of myoglobin and $\mathrm{H}_{2} \mathrm{O}_{2}$ as followed by direct photometric measurement of the formation of ferryl myoglobin. (A) Formation of ferryl myoglobin. The solution contained $\mathbf{0 . 2 2}$ $\mu \mathrm{M}$ metmyoglobin. See text for details. (-), before irradiation; (---), after irradiation; ( . .), $1 \mathrm{~min}$ after the solution was made $1.2 \mu \mathrm{M}$ in $\mathrm{H}_{2} \mathrm{O}_{2}$. (B) Absorbance change at $432 \mathrm{~nm}$ with time. $\mathrm{H}_{2} \mathrm{O}_{2}$ was added as indicated by the arrow. The slower step corresponds to ferryl myoglobin conversion to metmyoglobin. 
hemeproteins. The overall reaction is: Flavin $-\mathrm{H}_{2}+\mathrm{H}_{2} \mathrm{O}_{2} \rightarrow$ Flavin $+2 \mathrm{H}_{2} \mathrm{O}$. In contrast to the use of direct spectrophotometry for measuring the rate of formation of the higher valence states of hemeproteins, the coupling method described in this paper is not limited to those hemeproteins which yield stable oxidation products in the presence of peroxide. Horseradish peroxidase, myoglobin, and cytochrome $c$ all remain intact under the conditions of the assay (Fig. 3). The peroxidation reactions are zero-order with respect to dihydroriboflavin, indicating that this compound reduces the products of the peroxidation reaction rapidly, thereby protecting the hemeprotein from being destroyed and making the peroxidation reaction the rate-limiting step. The reduced flavin plays two additional roles in the assay-it serves in the photochemical reduction reaction to shuttle reducing equivalents from EDTA to hemeproteins and it serves as the reagent the disappearance of which is used as a measure of the overall coupled reaction.

Whereas the procedure is effective in measuring the rate of peroxidation for each of the three hemeproteins, each peroxidation proceeds by a different scheme. Horseradish peroxidase, which remains predominantly in its ferric form throughout the procedure, catalyzes the peroxidation of dihydroriboflavin as follows:

$$
\begin{aligned}
& \text { Horseradish peroxidase-Fe(III) }+\mathrm{H}_{2} \mathrm{O}_{2} \rightarrow \text { Compound } \mathrm{I}+\mathrm{H}_{2} \mathrm{O} \\
& \text { Compound } \mathrm{I}+\text { Flavin } \cdot \mathrm{H}_{2} \rightarrow \text { Horseradish peroxidase-Fe(III) }+ \text { Flavin }+\mathrm{H}_{2} \mathrm{O}
\end{aligned}
$$

The rate constant of $6.2 \times 10^{6} \mathrm{M}^{-1} \mathrm{~s}^{-1}$ obtained in this procedure may be assigned to the rate-limiting step, the formation of Compound I. This value is similar to the value of $10^{7} \mathrm{M}^{-1} \mathrm{~s}^{-1}$ reported for rate constant of the direct photometric measurement of the formation of Compound I (3) and the value of $2 \times 10^{6} \mathrm{M}^{-1} \mathrm{~s}^{-1}$ measured at $\mathrm{pH} 6$ in a coupling system using the redox dye 2,2'-azinobis(3-ethylbenzthiazoline-6-sulfonate) as the coupler (23).

In contrast, myoglobin catalyzes the reaction between $\mathrm{H}_{2} \mathrm{O}_{2}$ and dihydroriboflavin as follows:

$$
\begin{array}{ll}
\text { Myoglobin-Fe(II) }+\mathrm{H}_{2} \mathrm{O}_{2} & \rightarrow \text { Myoglobin-Fe(IV)O }+\mathrm{H}_{2} \mathrm{O} \\
\text { Myoglobin-Fe(IV)O }+ \text { Flavin- } \mathrm{H}_{2} & \rightarrow \text { Myoglobin-Fe(II) }+ \text { Flavin }+\mathrm{H}_{2} \mathrm{O}
\end{array}
$$

Prior to adding $\mathrm{H}_{2} \mathrm{O}_{2}$, irradiation in the presence of EDTA yields dihydroriboflavin which in turn reduces ferric myoglobin. Adding $\mathrm{H}_{2} \mathrm{O}_{2}$ generates ferryl myoglobin in the rate-limiting step (24, 25 ), and the ferryl myoglobin then rapidly oxidizes dihydroriboflavin. This scheme is confirmed by the results of the direct spectrophotometric measurement of ferryl myoglobin formation (Fig. 4). The observed rate constant of $8.0 \times 10^{4} \mathrm{M}^{-1} \mathrm{~s}^{-1}$ for the direct measurement agrees well with the value of $7.5 \times 10^{4} \mathrm{M}^{-1} \mathrm{~s}^{-1}$ obtained with the coupled system. Previously, the value for $k$ had been inferred from a variety of experiments to be much greater than $10^{3} \mathrm{M}^{-1} \mathrm{~s}^{-1}(18,24,25)$.

Unlike peroxidase and myoglobin, cytochrome $c$ does not readily bind and activate $\mathrm{H}_{2} \mathrm{O}_{2}$ to form a ferryl state, but nonetheless is bleached by peroxides (13) and induces lipid peroxidation $(13-16,26)$. The catalysis of dihydroriboflavin peroxidation by cytochrome $c$ observed in the present study is proposed to proceed by the following scheme involving a Fenton-type reaction: 


$$
\begin{aligned}
& \text { Cytochrome } c \text { - } \mathrm{Fe}(\mathrm{II})+\mathrm{H}_{2} \mathrm{O}_{2} \rightarrow \text { Cytochrome } c-\mathrm{Fe}(\mathrm{III})+\mathrm{OH} \cdot+\mathrm{OH}^{-} \\
& \text {Cytochrome } c-\mathrm{Fe}(\mathrm{III})+\text { Flavin } \cdot \mathrm{H}_{2}+\mathrm{OH}^{-} \rightarrow \text { Cytochrome } c-\mathrm{Fe}(\mathrm{II})+\text { Flavin-H} \cdot+\mathrm{H}_{2} \mathrm{O} \\
& \text { OH. }+ \text { Flavin } \cdot \mathrm{H}_{2} \rightarrow \mathrm{H}_{2} \mathrm{O}+\text { Flavin-H. } \\
& 2 \text { Flavin-H. } \rightarrow \text { Flavin } \cdot \mathrm{H}_{2}+\text { Flavin }
\end{aligned}
$$

Reaction 5 would be rate-limiting, and oxidation of dihydroriboflavin would proceed rapidly by its reactions with ferricytochrome $c$ and hydroxy radical. Reaction 5 has been proposed as the initial reaction between ferrocytochrome $c$ and $\mathrm{H}_{2} \mathrm{O}_{2}$ (27) and reactions 6,7 , and 8 have been reported to proceed rapidly (28-30). We propose that the bleaching of cytochrome $c$ which we observe in the absence of dihydroriboflavin results from reaction of cytochrome $c$ with hydroxy radical, and that dihydroriboflavin protects cytochrome $c$ by reducing the hydroxy radical. The reported cytochrome $c$-dependent oxidation of membranes might likewise be attributed to hydroxy radicals generated by such a redox cycle, rather than to radicals generated by iron released from cytochrome $c$ (13).

Our results show that coupling to dihydroriboflavin is a useful tool with which to investigate peroxidation reactions of peroxidases and non-peroxidase hemeproteins. Its usefulness arises from its rapid reaction with the higher oxidation states of hemeproteins and hydroxy radical. Oxidations of hemeproteins by either superoxide or peroxides and related radical generations are currently under intense study because of their relevance to cellular damage. Our results suggest that flavins might be good candidates as therapeutic agents for decreasing the oxidative damage resulting from processes like ischemia and reperfusion. Arguments have been made that reducing compounds could diminish the extent of ferryl myoglobin production and / or increase the rate of ferryl state myoglobin reduction during reperfusion (31-34). Reduced riboflavin is an appealing candidate for use as such a therapeutic agent because this naturally occurring compound can enter cells, is readily reduced intracellularly, and is non-toxic at effective concentrations.

ACKNOWLEDGMENT: This study was supported by USPHS NIH Grant AG-07046.

\section{REFERENCES}

1. Dunford, H. B. (1982) in Advances in Inorganic Biochemistry (Eichhorn, G. L., and Marzilli, L. G. eds.), Vol. 4, pp. 41-68, Elsevier, New York.

2. Hewson, W. D., and Hager, L. P. (1979) in The Porphyrins (Dolphin, D., ed.), Vol. 7, pp. 295-332, Academic Press, New York.

3. Yamazaki, I., and Yokota, K. (1973) Mol. Cell. Biochem. 2, 39-52.

4. Rice, R. H., Lee, Y. M., and Brown, W. D. (1983) Arch. Biochem. Biophys. 22 1, 417-427.

5. Clemens, M. R., Einsele, H., Remmer, H., and Waller, H. D. (1985) Biochem. Pharmacol. 34, 1339-1341.

6. Ko, K. M., and Godin, D. V. (1991) Mol. Cell. Biochem. 101, 23-29.

7. Catalano, C. E., Choe, Y. S., and Ortiz de Montellano, P. R. (1989) J. Biol. Chem. 264, 10534-10541.

8. Prasad, M. R., Engelman, R. M., Jones, R. M., and Das, D. K. (1989) Biochem. J. 263, 731-736.

9. Giulivi, C., and Davies, K. J. A. (1990) J. Biol. Chem. 265, 19453-19460.

10. George, P., and Irvine, D. H. (1952) Biochem. J. 52, 511-517. 
11. King, N. K., and Winfield, M. E. (1963) J. Biol. Chem. 238, 1520-1528.

12. Fox, J. B., Nicholas, R. A., Ackerman, S. A., and Swift, C. E. (1974) Biochem. 13, 5178 5186.

13. Radi, R., Turrens, J. F., and Freeman, B. A. (1991) Arch. Biochem. Biophys. 288, 118-125.

14. Kanner, J., and Harel, S. (1985) Arch. Biochem. Biophys. 237, 314-321.

15. Kaschnitz, R. M., and Hatefi, Y. (1975) Arch. Biochem. Biophys. 171, 292-304.

16. O'Brien, P. J. (1969) Can. J. Biochem. 47, 485-492.

17. Tappel, A. L., (1955) J. Biol. Chem. 217, 721-733.

18. Galaris, D., Eddy, L., Arduini, A., Cadenas, E., and Hochstein, P. (1989) Biochem. Biophys. Res. Comm. 160, 1162-1168.

19. Eddy, L., Arduini, A., and Hochstein, P. (1990) Am. J. Physiol. 259, C995-C997.

20. Yubisui, T., Matsukawa, S., and Yoneyama, Y. (1980) J. Biol. Chem. 255, 11694-11697.

21. Massey, V., Stankovich, M., and Hemmerich, P. (1978) Biochem. 17, 1-8.

22. DeFilippi, L. J., Ballou, D. P., and Hultquist, D. E. (1979) J. Biol. Chem. 254, 6917-6923.

23. Childs, R. E., and Bardsley, W. G. (1975) Biochem. J. 145, 93-103.

24. Yusa, K., and Shikama, K. (1987) Biochem. 26, 6684-6688.

25. Whitburn, K. D. (1987) Arch. Biochem. Biophys. 253, 419-430.

26. Simon, F. P., Horwitt, M. K., and Gerard, R. W. (1944) J. Biol. Chem. 154, 421-425.

27. Sadrzadeh, S. M. H., Graf, E., Panter, S. S., Hallaway, P. E., and Eaton, J. W. (1984) J. Biol. Chem. 259, 14354-14356.

28. Massey, V., Palmer, G., and Ballou, D. (1973) in Oxidases and Related Redox Systems (King, T. E., Mason, H. S., and Morrison, M., eds.) Vol. 3, pp. 25-49, University Park Press, Baltimore.

29. Hazzard, J. T., Moench, S. J., Erman, J. E., Satterlee, J. D., and Tollin, G. (1988) Biochem. 27, 2002-2008.

30. Land, E. J., and Swallow, A. J. (1969) Biochem. 8, 2117-2125.

31. Yamada, T., Volkmer, C., Grisham, M. B. (1991) J. Free Radic. Biol. Med. 10, 41-49.

32. Mitsos, S. E., Kim, D., Lucchesi, B. R., and Fantone, J. C. (1988) Lab. Invest. 59, 824-830.

33. Arduini, A., Eddy, L., and Hochstein, P. (1990) Arch. Biochem. Biophys. 28 1, 41-43.

34. Buffinton, G., and Cadenas, E. (1988) Chem. Biol. Interact 66, 233-250. 